\title{
The Impact of Structure Change on Copper Prices
}

\author{
Kegomoditswe Koitsiwe ${ }^{1^{*}}$ and Tsuyoshi Adachi ${ }^{2}$ \\ ${ }^{1}$ Graduate School of Engineering and Resource Science, Akita University, Japan \\ ${ }^{2}$ Graduate School of International Resource Science, Akita University, Japan
}

\begin{abstract}
This paper characterizes quarterly LME copper price fundamentals from 1995 to 2011 by analyzing the transformation of the market mechanism based on structural change perspective. Using chow test for structural change based on the least square multiple regression, we divide the price fluctuation into: Stable price period (1995Q3-1999Q2), Low stable price period (1999Q3 - 2003Q3) and Price fluctuation period (2003Q4 - 2011Q2). The results show the existence of structural breaks disproves the investigation of the full sample period as a whole. In different structural breakpoints the main drivers of copper prices changes and their impact are significantly different. Moreover, the paper examines the role of speculation in copper price fluctuations.
\end{abstract}

Keywords: copper price fundamentals, speculation, structural breaks

\section{Introduction}

The rise in commodities price volatility and financial and economic crisis have led to questions over the organisation of futures and physical commodities markets. Spikes in commodity prices and volatility have coincided with a surge in financial speculators in the commodity markets inspiring a polarised and hotly debate among academics and practitioners about the role of investors in the development of physical markets. In his seminal work Kaldor (1939) focused primarily on whether speculative activity in the futures markets reduces the variance of commodity spot prices. Yet, part of the literature finds that the introduction of futures contracts destabilizes the spot market. IMF (2006) studied commodities boom and its causes concluding that there is little support for the hypothesis that speculative activity affects either price levels over the long run or price swings in the short-run. The impact of speculative activity on commodity prices remains a highly contentious topic. Other market analysts take the view that the supply and demand for physical commodities remain the major determinants of market trends (Krugman 2008). It is the aim of this study to contribute to the literature by examining the drivers of copper price changes from a structural change perspective. In this context we are attempting to answer to: What are the main drivers leading to copper price fluctuations? Are these factors having the same effect in different periods or not? It is meaningful to understand drivers of copper prices and thereby, their fluctuations because it will help developing countries depending on copper export to anticipate market situation and avoid bad economic development challenges that can result from price fluctuations. Moreover, this can ensure sustainable mineral supply.

\section{Investment in Commodity Markets}

Investing in commodities is subject to greater scrutiny due to the implication that demand and supply patterns in these markets may have on the economy at large. Financial crisis has seen an increase in the weight of investors shifting from purely financial asset classes to instruments with an underlying commodity or close proxy. This is because commodities do not easily go out of market therefore can be used as an inflation hedge. Investing directly in commodities is however, very costly due to the unpredictable factors that can change their price patterns and cash needed to cover daily margin calls for marked-to market futures positions. The investment strategies in commodities are manifold.

Investors can buy and sell commodity futures and traded options on exchanges, such as London Metal Exchange (LME) or the New York Commodity Exchange (COMEX). Deals can be directly conducted over-thecounter (OTC). They can buy commodity-based Exchange Traded Funds or buy and take physical possession of commodity stocks. Investors use the markets to hedge their business from the various risks linked to commodities. Another trading objective is generated from the need for liquidity or funding relief (Aramendía and Lannoo 2012). Spotting a divergence between futures and spot prices at maturity is an example of arbitrage. If the future price at maturity is lower than the spot price, the commodity firm will exploit this situation by buying the futures rather than the spot. The important aspect of this transaction is that is a risk-free operation. Informed trading, also known as speculation is a form of trading based on investments in private information, which the trader exploits to generate profits.

* Corresponding Author: K. Koitsiwe, kegomoditswek@yahoo.com, phone: +81 80-6292-3841

Copyright @ 2017 Canamaple Academia Services, http://press.camdemia.ca

DOI: 10.15273/gree.2017.02.013 
Informed trading can be separated into two main categories, trend spotters (speculators) aiming at anticipating the trend in future or spot prices and index investing. The former can go both long and short in the market; they can also take positions using traded options. Thus they can benefit from price falling as well as rising commodity prices. The latter are the long-only commodity index funds, not very price responsive and are not easily stopped out of their positions. The two principal such funds were initially the Goldman Sachs Commodity Index fund (the now S\&P GSCI) and the DJ-AIG commodity index fund (now DJ-UBS). This study uses the futures contracts (open interest) to as an indicator for speculation activity in copper futures market.

\section{Previous Studies}

A central question is whether speculation in futures markets either through CITs or other speculators distorted spot prices. Verleger (2007), Kaufman (2010) are of view that growth of investors in the markets distort commodity prices. The major surge in metal and other commodity prices in the second half of 2005 and the first half of 2006 coincides with an acceleration of monies inflowing into commodity index funds and other speculations. Yet other market analysts take the view that the supply and demand for physical commodities remain the major determinants of market trends (Krugman 2008).

Work on the impact of the growing presence of financial investors on commodity prices are less clear-cut. Irwin and Sanders (2010) used commodity index traders data for 12 commodities to check for Granger causality between index fund positions and future returns. Although the study acknowledges that increased flow of index fund investment represents a structural change of the commodities market, they argue that it did not cause a bubble in commodity futures prices.

A number of studies have followed Irwin and Sanders methodology of examining the correlation between trader positions and change in prices. Stoll and Whaley (2011) used CIT data and conclude that index fund trading does not cause increase in futures prices. Out of the 12 commodities examined, only cotton net traders position does lead to future price changes.

Moreover, IMF (2010) revisited their 2006 study on the issue of speculation in commodities markets, maintaining their conclusion that fundamentals largely determine commodity prices as there is little evidence that financial investment has a significant sustained impact on commodity prices above and beyond current and expected supplydemand fundamentals.

UNCTAD discussion paper, Mayer (2009) finds significant impact of financial traders on prices of both agricultural and non-agricultural commodities. Similarly, Robles et al (2009) use four indicators: volume, open interest, ratio of monthly volume to open interest, and positions of non-commercial traders and conclude that speculative activities seem to have influential, but accept that the evidence is far from conclusive.
Gilbert (2010) carries out OLS, 2SLS, and 3SLS estimation of change in the agricultural food price index versus changes in the oil price, the exchange rate, and the futures investment index. The study arrives at similar conclusions from all three regressions - estimates show a statistically significant impact of index investment on both the food price index and oil price.

Brunetti et al (2010) use CFTC proprietary data for crude oil, natural gas, and corn that identifies positions of each trader category in each futures contract for every contract maturity on each day. They carry out Granger causality in the context of VAR from January 2005 to March 2009 using returns, positions, and realized volatility data. The paper concludes that speculative activity does not affect prices, and further that swap dealers and hedge funds reduce volatility.

Hong and Yogo (2012) use open interests of 30 commodities from 1964, they show that movements in open interest predict movements in prices even controlling for other known predictors of returns such as short rate, yield spread, and basis. In this study we follow Hong and Yong and use total open interest for commodity index funds and future contracts as a measure of total inflow of liquidity into the market, instead of trying to divide the open interest among different types of traders. Our study focuses primarily on drivers of copper price formation. This is because commodities may have common drivers of price formation but the impact of each driver on price patterns may be completely different depending on the type of commodity being analysed. Therefore a generalized approach across commodities, even with sophisticated statistical models may be unable to capture the significant divergences among commodities.

\section{Data and Methodology}

Our empirical analysis focuses on quarterly data from 1995 to 2011.

Copper spot prices sourced from London Metal Exchange (LME) are used in this study. There are several reasons for focusing on spot prices: first, these are the most commonly quoted prices and London prices reflect market prices and has been and still is the principal marketplace to establish prices in copper market. Second, the effects of speculations on futures markets for futures prices do not seem particularly controversial (Tilton et al 2011).

Copper Stock is sourced from LME. For metal commodities, inventory levels are primarily affected by the business cycles mainly through world GDP (Fama and French 1988). Changes in the inventory levels have effects on spot and futures prices, which react differently to the high or low levels of inventories.

To test the potential role of business-cycle on copper spot market, DJ-AIG commodity index and S\&P500 are used as proxies. These indexes are most commonly followed equity indexes and classified the leading indicators of business cycle.

Commitment of traders announced by Commodity Futures Trading Commission (CFTC) can be used to 
measure the scale of arbitrage trading and speculative trading. Instead of using trading positions of different categories of traders we use total open interest representing futures contracts, the reason being that although the rise of institutional investors is an important aspect of financialization, other aspects such as the changing role of 'bonafide hedgers' and the entry of money managers and hedge funds into the market are just as important. Taking the entire open interest into consideration enables us to explore the implication of speculation in a broader sense instead of focusing on the activities of index traders. Studying the developments in open interest and prices allows us to examine if the rapid inflow of liquidity into commodity markets lead to price bubbles.

LME Stock, Dow and Jones index and copper prices trends, 1995Q2 to 2011Q2.

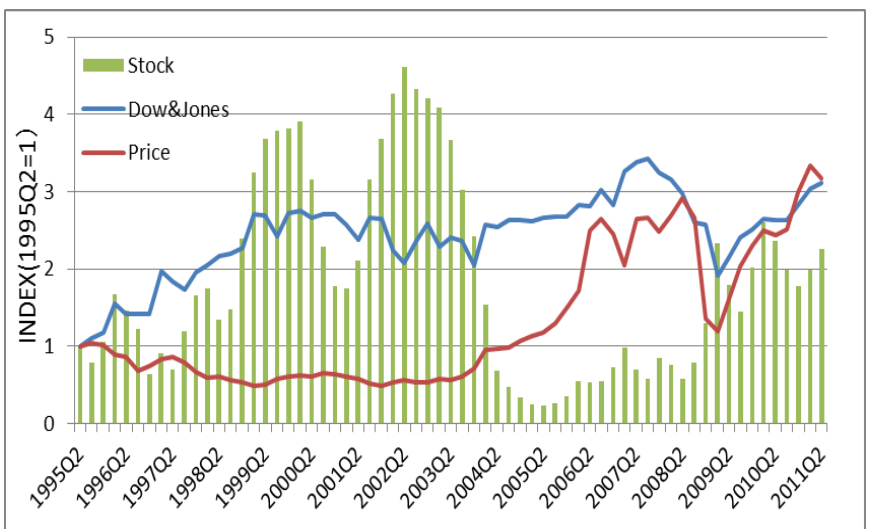

Figure 1: Chronological change of Dow Jones, stockpile and copper price (US\$).

Source: LME, Dow and Jones

Figure 1 indicates that there is an inverse relationship between stock and coper price. Moreover, from 2004Q2 2011Q2 Dow Jones index moves together with the price.

Futures Contracts, Copper prices and Standard \& Poor's 500 trends, 1995Q2 to 2011Q2

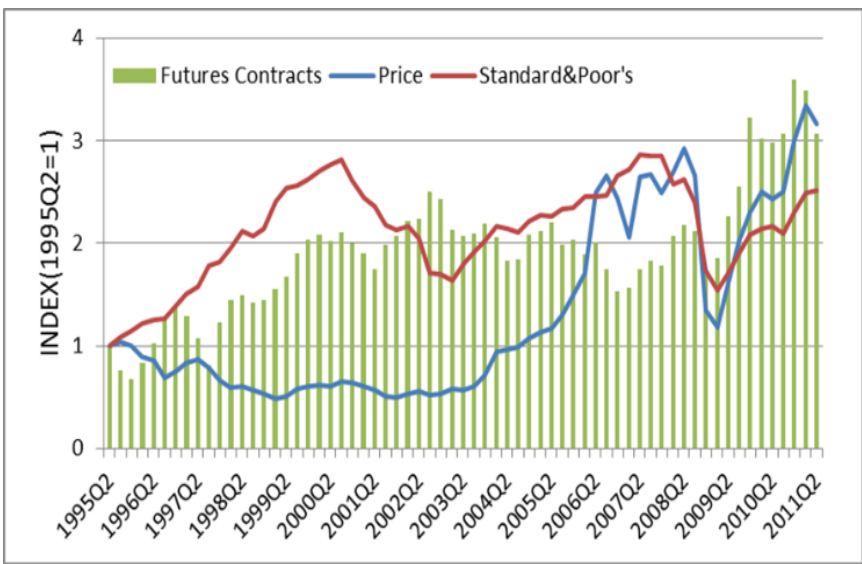

Figure 2: Chronological change of copper price, S\&P and Futures trading volume.

Sources: LME, CFTC and S\&P
Figure 2 shows a rise in S\&P index while prices are low. From 2003Q2 copper prices move together with the index. There is an increase in all variables from 2009Q2 to 2011Q2.

\section{Research Method}

This study uses ordinary least squares (OLS) to examine linear relationship between copper spot price and independent variables (lagged copper spot prices, Dow Jones Industrial Average (DJIA), LME stock and Futures Contracts). This can be expressed as:

$$
\ln P_{t}=A^{\prime}+\alpha \ln P_{t-1}+\beta \ln D J_{t}+\gamma \ln S_{t}+\varepsilon \ln F_{t}+\varepsilon_{t}
$$

To set the stage for the analysis verification of the statistical properties of the time series variable is necessary. This is done to avoid spurious regression caused by the presence of unit root. Accordingly, we employed Augmented Dickey Fuller test and Phillip and Perron test to check for the stationarity of the all the concerned variables. Moreover the study use chow test to examine the presence of structural break points in the time series data.

\section{Results}

The results indicate only significant variables to explain drivers of copper spot prices based on the t-value (which is indicated in the parenthesis below the regression equation), $\mathrm{R}$-squared and Durbin Watson value.

The regression output indicate that Dow and Jones index influence copper. A $10 \%$ rise (fall) in the stock index correlated with $10.1 \%$ rise (fall) in copper spot price. Movements in lagged copper prices exerted the second influence on copper, a $10 \%$ rise in lagged prices tended to send copper prices about $1.6 \%$ higher. LME stockpile have an inverse relationship with copper prices perhaps as a result of the interaction between demand and supply. A $10 \%$ rise in LME stockpile is correlated to $1.6 \%$ decrease of copper prices.

$$
\begin{gathered}
\Delta \ln P_{t}=0.0024+0.16 \Delta \ln P_{t-1}+1.01 \Delta D J_{t}-0.16 \Delta \ln S_{t} \\
(0.16) \quad(1.56) \\
\mathrm{R}^{2}=0.43, \mathrm{DW}=1.62
\end{gathered}
$$

Structural break point

The chow test was used to identify structural break points in 1999Q2 and 2003Q3.The data was split into three periods; stable price period, moderate price period and price fluctuation period.

Stable price period (1995Q3-1999Q2)

The regression output show that copper price is influenced by lagged prices, Dow Jones index and LME inventories. A $10 \%$ rise (fall) in Dow and Jones index is correlated to $9.9 \%$ rise (fall) in copper spot prices. Moreover, lagged copper prices have an influence on the copper spot price. A $10 \%$ rise in lagged prices is correlated to $3.6 \%$ rise in copper spot prices. An inverse relationship between copper spot price and inventories is revealed. 


$$
\begin{gathered}
\begin{aligned}
\Delta l n P_{t}=-0.071 & +0.36 \Delta \ln P_{t-1}+0.99 \Delta \ln D J_{t} \\
& -0.13 \Delta \ln S_{t} \\
(-2.05) \quad(1.43) & (2.22)
\end{aligned} \\
\mathrm{R}^{2}=0.43 ; \mathrm{DW}=2.21
\end{gathered}
$$

Low stable price period (1999Q3 - 2003Q3)

The results indicate that during the period 1999Q3 2003Q3 only lagged copper prices and Dow and Jones stock index influenced copper spot prices. Lagged copper prices influenced the spot price by $2.5 \%$ while the index by $6.4 \%$.

$$
\begin{gathered}
\Delta \ln P_{t}=0.013+0.25 \Delta \ln P_{t-1}+0.64 \Delta \ln D J_{t} \\
\mathrm{R}^{2}=0.33 ; \mathrm{DW}=1.73
\end{gathered}
$$

Price fluctuation period (2003Q4 - 2011Q2)

This is a period of copper price fluctuations. The regression output indicates that S\&P500 and futures contracts influenced the copper spot prices. The results indicate the influence of inflow of money in the copper market.

$$
\begin{gathered}
\Delta \ln P_{t}=0.034+1.53 \Delta \ln S P_{t-1}+0.47 \Delta \ln F_{t} \\
(1.66) \quad(5.64) \\
\mathrm{R}^{2}=0.66 ; \mathrm{DW}=1.64
\end{gathered}
$$

\section{Conclusion and Future prospects}

This study attempts to examine main drivers of copper price changes from a structural change perspective. Moreover, the role of speculation on copper price changes are investigated. The results based on linear regression model and chow test indicate that lagged copper price changes influence copper price changes only during period of stability. In addition the results indicate that stock pile have an inverse relationship with copper price changes and influenced them during period of stability. The inverse relationship is as a result of demand and supply interactions. Additionally, we find the influence of speculators in the copper market. In the period 2003Q4 to 2011Q2, copper price changes are influenced by the inflow of speculative money. Although the results appear to support that inflow of money in the copper market influence the copper price changes further research is needed to better understand the role of financial investors in copper market to provide comprehensive policy implications especially for developing countries that depend on copper as a source of income and foreign exchange and also to ensure sustainability of copper supply.

\section{Acknowledgement}

We would like to acknowledge the Japanese Ministry of Education, Culture, Sports, Science and Technology
(MEXT) and Akita University Leading Program for the financial support.

\section{References}

Aramendía, M.D.M. and K. Lannoo, 2012. Rethinking asset management. CEPS-ECMI Task Force Report, CEPS Paperback.

Brunetti, C., B. Buyuksahin and J.H. Harris, 2010. Is Speculation Destabilizing? http://citeseerx.ist.psu.edu/viewdoc/download?doi=10.1 1.357.8949\&rep=rep1\&type=pdf.

Fama, E.F. and K.R. French, 1988. Business cycles and the behavior of metals prices. Journal of Finance, (43): 1975 - 1093.

Gilbert, C.L., 2010. How to understand high food prices. Journal of Agricultural Economics, 61(2): 398 - 425.

Hong, H. and M. Yogo, 2012. What does futures market interest tell us about the macroeconomy and asset prices. Journal of Financial Economics, 105(3) 473 - 490.

IMF, 2006. World economic outlook, International Monetary Fund, Washington, DC.

IMF, 2010. Global prospects and policies. International Monetary Fund, Washington, DC.

Irwin, S.H., and D.R. Sanders, 2010. Speculation and financial fund activity: draft report, annex 1 . Proceedings of OECD Working Party on Agricultural Policies and Markets.

Kaufman, F., 2010. The food bubble. Harper's Magazine. http://frederickkaufman.typepad.com/files/the-foodbubble-pdf.pdf.

Kaldor, N., 1939. Speculation and economic stability. Review of Economic Studies, 7(1): 1 - 27.

Krugman, P., 2008. The oil nonbubble. New York Times. http://www.nytimes.com/2008/05/12/opinion/12krugma n.html.

Mayer, J., 2009. The growing interdependence between financial and commodity markets. Unctad Discussion Paper, 195.

Robles, M., M. Torero and J.V. Braun, 2009. When speculation matters. IFPRI Issues Brief, International Food Policy Research Institute. Washington DC.

Stoll, H.R. and R.E. Whaley, 2010. Commodity index investing and commodity futures prices. Journal of Applied Finance, (20): 7 - 46.

Tilton, J.E., D. Humphreys and M. Radetzki, 2011. Investor demand and spot commodity prices. Resource Policy, (36): 187 - 195 .

Verleger, P.K., 2007. How wall street controls oil. International Economy, 21(1): 14. 